Pastor, Peter. "The Travelogues of Gyula Illyés and Lajos Nagy on Their Visit to the Soviet Union." Hungarian Cultural Studies. e-Journal of the American Hungarian Educators Association, Volume 11 (2018) DOI:

\title{
The Travelogues of Gyula Illyés and Lajos Nagy on Their Visit to the Soviet Union
}

\section{Peter Pastor}

\begin{abstract}
The Hungarian populist writers Gyula Illyés and Lajos Nagy visited the Soviet Union together during the summer of 1934 as guests of the Union of Soviet Writers. Upon their return to Hungary, Illyés and Nagy published their impressions in separate travelogues.Although they both stressed that they strived for objectivity in their travel reports, they did not fully succeed in their efforts. Their perspectives were colored by a feeling of cultural superiority carried over from their experiences in the Hungary of the 1930s. Their writing was also tainted with anti-Semitism, as evidenced by their reflections on the life of Jews in Russia and Ukraine. Although their hosts took them to model institutions on a government-designed grand tour, they were not won over to the communist cause and failed to become fellow travelers.
\end{abstract}

Keywords: Gyula Illyés, Lajos Nagy, Georges Duhamel, Luc Durtain, travel in the USSR, Russian Revolution, communism

Biography: Peter Pastor is Professor Emeritus at Montclair State University in New Jersey. His special interest is twentieth century diplomatic history and Hungarian-Soviet relations. He is the author or editor of several scholarly books and close to fifty articles. A number of his articles were published in Hungarian academic journals. pastorp@montclair.edu

During the interwar years, the communist Soviet Union, the home of the "New Soviet Man," was in the forefront to offer a new cultural model to the Western visitor. Soon after the Bolshevik Revolution of 1917, the American muckraking journalist, Lincoln Steffens, following his return from Soviet Russia noted, "I have been over into the future and it works" (Steffens 1931:799). His declarations indicated that there was much to be learned from the Soviet utopia. The Soviet leaders, most importantly Stalin, recognized that such accolades helped to promote the interest of the state abroad (Stern 2007: 90). Therefore, the propagation of a positive image through the invitation to the USSR of eminent foreign intellectuals, most importantly writers, became a cornerstone of Soviet cultural diplomacy (Cœuré and Mazuy 2012: 10-11, 56).

\footnotetext{
* This paper is a slightly revised version of "Illyés Gyula és Nagy Lajos útinaplója szovjetunióbeli látogatásáról," published in Múltunk 62 (1) 2017: 116-134. All translations are by the author.
}

$(\mathrm{cc}) \mathrm{BY}$ ULIS D-Sente
New articles in this journal are licensed under a Creative Commons Attribution 4.0 International License.

This journal is published by the University Library System of the University of Pittsburgh as part of its D-Scribe Digital Publishing Program and is cosponsored by the University of Pittsburgh Press 
Pastor, Peter. "The Travelogues of Gyula Illyés and Lajos Nagy on Their Visit to the Soviet Union.” Hungarian Cultural Studies. e-Journal of the American Hungarian Educators Association, Volume 11 (2018) DOI:

In the 1930s, when a good number of Western writers were guests of various Soviet organizations, two prominent left-wing populist Hungarian writers, Gyula Illyés and Lajos Nagy, were invited by the Union of Soviet Writers to visit the Soviet Union. Their two-months-long tour in the summer of 1934 was financed by the Soviet state and had as its final goal the attendance of the First All-Union Congress of Soviet Writers. Just as in the case of most other visitors, the two Hungarian writers perceived the Soviet Union as terra incognita ['unknown territory'] (Mazuy: 9), ready to be discovered. Towards the end of 1927 Gyula Illyés already noted that, "Even as travel literature fills libraries the Western world still does not know a lot about Soviet Russia, which is celebrating the tenth anniversary of its establishment" [De a könyvtárakra menö útleírások után, még ma sem tud igen többet a nyugati világ a fennállásának immár tízedik évfordulóját ünneplö Szovjet-Oroszországról] (Illyés 1927).

Upon their return to Hungary, Illyés and Nagy published their impressions in separate travelogues. Even though the first-time visitors to the USSR traveled together on a predetermined route selected by their hosts, they did not always find the same significance in what they saw. This is understandable, as seeing is a process and as such what one sees is colored by the previous experiences of the observer. What they shared, however, was their feeling of cultural superiority over the society they visited. Their condescending view, as articulated or hinted at in their published travel writings, was also colored by anti-Semitism, which in Hungary was all-pervasive and officially perpetuated during the Horthy era.

Gyula Illyés, who published his travelogue in book form in November 1934, gave a hint of his approach to future travel writing in his December 1927 review essay in the literary journal Nyugat ['West'], of Georges Duhamel's Le Voyage de Moscou ['The Moscow Trip']. Illyés, who from the end of 1921 lived in exile, mostly in Paris, returned to Budapest in 1926 after having been amnestied by the Horthy regime. His fluent French and Parisian experience (Babus 2015: 12) made him the ideal reviewer of Duhamel.

In his essay Illyés praised the French traveler as he declared that "Perhaps no one has looked around Russia more objectively and with an understanding glance than Duhamel. The majority of the travelers who hitherto had gone there knew beforehand what he/she had wanted to see and did not see or at least did not relate anything that did not buttress their sociological and moral perception"'[Duhamelnél objektivebben, mindenfelé ilyen egyformán megértö pillantással tán még senki sem nézett körül Oroszországban. Az eddigelé ottjárt utazók legnagyobb része eleve tudta, mit akar Oroszországban látni, s nem is látott vagy legalább is nem mondott el mást, mint ami a saját szociológiai vagy erkölcsi felfogását alátámasztotta]. Duhamel, Illyés noted, went to Russia with no preconceptions and was interested in meeting the "common man" [két lábon járó embert]. Illyés nevertheless stressed what he saw as the weakness of this approach: with the focus being on the common man the reader "hardly sees a kind of picture... about the creators and sustainers of the New Russia; in the entire book there is not one word about the workers. Not one word about the organization of the state, of production" [alig lát valami horizontot...az Új Oroszország megteremtőiröl és fenntartóiról, a munkásságról egy szó sem esik az egész könyvben. Egy szó sem az állam, a termelés szervezetéröl] (Illyés 1927).

Be that as it may, Illyés as reviewer of Duhamel claimed that he gained from the "lyric mosaics" [lírai mozaikokból] of the latter the image of contemporary Russia as an amalgam of old Russia and the modern West: "The muzhik lives in the same room with his domestic animals 
Pastor, Peter. "The Travelogues of Gyula Illyés and Lajos Nagy on Their Visit to the Soviet Union." Hungarian Cultural Studies. e-Journal of the American Hungarian Educators Association, Volume 11 (2018) DOI:

and the cows chewing on their cud under the bright electric lights as they listen with amazement to the clatter of the sewing machine" [A muzsik egy szobában lakik háziállatjaival s a kérödzö tehenek az éles villanyvilágítás alatt csodálkozva hallják a varrógép csattogását.] This picture, in fact, encompasses Illyés's lyrical imagination for in his book Duhamel does not speak of electric lights, nor of cows living in the same room with the Russian peasant. He does not even mention the clattering of the sewing machine, which is most likely pedal-driven, just as the one Illyés mentions in his travelogue when in the Soviet frontier village of Negoreloe he peeks through a window of a peasant hut and sees a sewing machine under the kerosene wick lamp hanging from the ceiling (Illyés 1974: 19). Instead, Duhamel writes: "Boris Pilniak took us to visit the village. It is still humble and miserable. The peasants in their log houses, where the little calf is neighbor to the sewing machine, make me think of all the peasants of the world, for example, our extinct peasantry of the Cévennes..." [Boris Pilniak nous mena visiter le village: il est toujours humble et misérable. Les paysans, dans leurs maisons de madriers, où le petit veau voisine avec la machine à coudre, me firent songer à tous les paysans du monde, à nos paysans cévenols, par exemple, qui ne sont pas encore...] (Duhamel 1927: 57-58).

Illyés's further example of the old and new is Duhamel's reaction to the telephone, which in the 1920s was the epitome of modernity. Illyés attributes to Duhamel the claim that it is used in Russia to carry on old-fashioned endless debates: "The telephone primarily serves an ancient preoccupation, the long and endless argumentation mania, that excessive social spirit that Jacques Rivière called goût du soviet [taste for debate] even during the war, which by now begins to reach dangerous proportions"' $A$ telefon legelsösorban a legrégibb tulajdonság, a végehosszatlan vitatkozási mániát szolgálja, azt a túlzott társadalmi kedvet, amit Jacques Rivière még a háború alatt nevezett el gout [sic] du soviet-nek, s amely most már kezd veszélyes arányokat ölteni] (Illyés 1927). The problem with the example offered by Illyés, however, is that in his récit de voyage ['travelogue'] Duhamel claims just the opposite: a Russian likes getting together not to debate but to "find in the physical and spiritual contact, a new and intoxicating warmth, a principle of trust" [Il aime de s'assembler, moins encore, je pense, pour débattre ses affaires que pour chercher,dans le contact des corps et des âmes, une chaleur enivrante et neuve, un principe de confiance] (Duhamel 1927: 36). According to Duhamel, it is this collective sociability that was noted by Rivière with the expression "le phénomène du soviet" [the soviet phenomenon], and not "gout du soviet" as claimed by Illyés. Moreover, Duhamel does not say that the term was introduced by Rivière during the war, only that Rivière had noted during the war a natural tendency among the Russians to stick together and take counsel (Duhamel 1927: 37, Rivière 1984: 154). In fact, Rivière coined the term after the war, in 1919, as he saw in the communist system of soviets the continuation of an unwelcome Russian collective tradition which denies "individual freedom" (Rivière 1984: 156). In his wartime diary entry Rivière noted: "the French exist as individuals before they exist as social beings. We could say the opposite of the Russians" [Les Français existent à l'état individuel, avant d'exister à l'état social. On pourrait dire le contraire des Russes] (Rivière 1995: 41).

Some thirty pages later Duhamel assails the seemingly eternal ringing of the telephone and the "rasgovor," the chat, which he claims is on the margin of conversation. Contrary to Illyés's reading, he does not relate this tendency to the Soviet phenomenon. Rather his criticism of the telephone usage of Russians is framed as an outcome of the clash between the old and new: "It does not help to overcome the fabled Slav inaccuracy, rather, it aggravates and complicates it" [Il ne pallie pas la fabuleuse inexactitude slave, mais l'aggrave et la complique] 
Pastor, Peter. "The Travelogues of Gyula Illyés and Lajos Nagy on Their Visit to the Soviet Union.” Hungarian Cultural Studies. e-Journal of the American Hungarian Educators Association, Volume 11 (2018) DOI:

(Duhamel 1927: 188). Clearly the misreading of Duhamel indicates that Illyés takes literary liberty in his review and reads into Duhamel's narrative what he perceives to be the truth. Therefore, he reveals in the book review his own subjectivity, his "sociological and moral grasp." Through his review of Duhamel he seems to foretell that he will take similar literary liberties in his own travel writing about Russia.

It is also noteworthy that in the review Illyés neglects to mention that Duhamel, who travelled in Russia on the invitation of the Academy of Artistic Sciences, was accompanied by his friend and fellow writer, Luc Durtain. Durtain's book on his Russian travels, entitled L'autre Europe. Moscou et sa foi ['The Other Europe. Moscow and Its Faith'], appeared in 1928 and was, no doubt, read by Illyés. In his own travelogue he questions Durtain's low estimate of the number of homeless street children at 200,000 to 300,000 (Illyés 1974: 173). This figure could only come from L'autre Europe (Durtain 1928: 211). Durtain, whose travelogue's style is closer to Illyés's than it is to Duhamel's, also mentions Duhamel as his travel companion throughout his book, starting with his train ride toward the Soviet frontier (Durtain 1928: 15).

Duhamel also indicates that he considered his travel companion's observations during the trip important and that is why he used the "I" and "we" pronouns interchangeably in his travelogue (Duhamel 1927: 15). The reviewer Illyés kept mum about Durtain, hinting that given the chance to travel with a fellow writer in Russia, his travelogue would appear as the reportage of a solitary traveler. Another practice that he did not borrow from Duhamel is the French visitor's tendency to compare his French experiences with what he saw in Russia. Instead he used an approach closer to Durtain's, which is not to contrast Russia with France or with any other nation (Kershaw, Hurcombe and Cornick 2017: 277). Illyés rarely contrasts Hungary with Russia and only over superficial issues, such as drinking or flirting. As one Hungarian specialist on Illyés's writings noted, the writer "Consciously avoided that on the basis of what he saw he would make critical comments on the conditions at home" [tudatosan elkerülte, hogy a látottak kapcsán a hazai viszonyokra tegyen bíráló megjegyzéseket] (Hammerstein 2007). Instead of making comparisons, Illyés notes that some of the seemingly novel Soviet practices had been embraced already independently in the West. For example, in his travelogue Illyés states: "Only in Russia is the number of modern measures taken by the Soviet a novelty" [A szovjetnek nem egy korszerü intézkedése csak Oroszországban újdonság] (Illyés 1974: 119). He also claims there that he did not intend to compare Soviet Russia with tsarist Russia and instead he wished to look at shortcomings in the construction of socialism: "During my stay in Russia I behaved as a counterrevolutionary. At every step I called for an account of the dream, which is as old as the human race. I tried to corner them with their own promises and slogans and was all ears to answers and explanations" [Oroszországi tartózkodásom alatt ellenforradalmárként viselkedtem, úton-útfélen számon kértem azt az álmot, amely oly idös, akár az emberiség. Saját igéreteikkel s jelszavaikkal igyekeztem sarokba szoritani őket, füleltem a választ, vagy a magyarázkodást ] (Illyés 34: 10). However, it should be noted that in the 1974 edition behaving as a counterrevolutionary was changed to behaving as a devil's advocate (Illyés 1974: 17). The literary historian, Ágnes Széchenyi, calls this literary device of Illyés a"rectified insertion at a later date" [utólag igazított közlés] (Széchenyi 2015: 64). It is likely that in this case the slight but meaningful change was necessitated by the fact that in 1962 Illyés made his peace with the communist Kádár regime and since the defeated 1956 Hungarian Revolution was termed by the authorities as a counterrevolution, it would not have been wise for Illyés to identify himself as a counterrevolutionary. 
Pastor, Peter. "The Travelogues of Gyula Illyés and Lajos Nagy on Their Visit to the Soviet Union.” Hungarian Cultural Studies. e-Journal of the American Hungarian Educators Association, Volume 11 (2018) DOI:

Although Illyés stressed in his travelogue that he only compared changes that had taken place since the establishment of the communist regime, he does note some continuity between tsarist and communist institutions. For example he states: "The foundation of society, the family, could not be crushed by the revolution. In another form and under other conditions it lives on steadfastly" [A családot, a társadalom alapját tehát a forradalom sem törhette össze. Más formában, más feltételekkel rendíthetetlenül tovább él] (Illyés 1974: 123). Looking at changes in Moscow, he traces the capital's history back to Ivan the Terrible (Illyés 1974: 37). In his criticism of some of the new construction he sees, his comparison is with the West and not Hungary (Illyés 1974: 41).

For the readers of his travelogue Illyés explained the purpose of his visit: "As elsewhere, here too I would have wanted to get to know the life of the people. And without prejudice, the system, which directs their fate now....I would have loved to see a moment of the proletarian revolution as objectively as if I were to arrive as Clio's reporter." [Mint mindenütt, itt is az emberek életét szerettem volna megismerni. És elfogulatlanul azt a rendszert, mely sorsukat most irányitja....A proletárforradalom egy pillanatát szerettem volna látni, oly szenvedélymentesen, mintha Klio tudósitójaként érkeztem volna] ( Illyés: 1974: 75). The positivist assumption, however, that Clio's historians could be completely objective was already questioned when Illyés expressed his goal of making detached observations in Russia. His intention reflected an approach to travel writing he identified in Duhamel's Le Voyage de Moscou. Duhamel's lasting impact on the Hungarian writer is further indicated by the fact that Illyés in his own travelogue repeats Duhamel's reference to the "phénomène du soviet" in the same twisted form he mentioned in his review: the "gout du soviet." Furthermore, Illyés falsely attributes to Jacques Rivière again the claim that the Russians love to debate (Illyés 1974: 72).

Since in his review he had criticized Duhamel for his failure to talk about the workers, in his own book Illyés made the point to report on them. Following his first encounter with workers in a ball bearings factory, however, he seems to change his mind and follows Duhamel's approach: "During my Russian trip the system interested me less than the people did. What could I conclude about them? ...I saw enough machinery. I would like to see human beings" [Oroszországi utamon nem annyira a rendszer érdekelt, mint az emberek. Mit állapíthattam meg róluk?...Gépet már eleget láttam. Embereket szeretnék látni] (Illyés1974: 89-90). All this demonstrates the intertextual aspect of travel writing (Hurcombe, Kershaw and Cornick 2017: 5), as Illyés followed Duhamel even in putting accent on meetings with the common man.

His change of heart about worker issues is reminiscent of Bernard Shaw's comment. After a while even this hardened supporter of the Soviet system had seen enough of workers on his visit to Russia in 1931 and declared: "The more I see of the proletarians the more I thank God I am not one" (Shaw 1964: 21). This declaration is symptomatic of the feeling of superiority that can be found in the accounts of Western visitors to the Soviet Union (David-Fox 2003: 300-301), including Duhamel and the two Hungarian visitors as well. Their sympathetic attitude towards communist Russia did not mean that they were willing to see Western traditions ditched for the sake of the Soviet (Caute 1973: 5).

While Illyés developed his ideas about the contents of a Russian travelogue through his readings of Duhamel's Le Voyage de Moscou, and through Durtain's accounts, Lajos Nagy, his travel partner, acquired his approach following his return from Russia through his reading of Illyés's travelogue, which was first published from the end of September to the end of October in a series under the title Ezt láttam Oroszországban ['This Is What I Saw in Russia'] in the daily 
Pastor, Peter. "The Travelogues of Gyula Illyés and Lajos Nagy on Their Visit to the Soviet Union." Hungarian Cultural Studies. e-Journal of the American Hungarian Educators Association, Volume 11 (2018) DOI:

Magyarország ['Hungary']. In December 1934 Nagy published in Nyugat his review of the book version of Illyés's travelogue, which had come out in November. He began his review by describing how they traveled together and that Illyés from the very beginning intended to write a book about his trip, and was making copious notes on whatever he saw. Nagy claimed that he, in contrast to Illyés, had had no intentions to write about his travel until he made his decision a week or two after his return to Budapest. He stated that although he took some notes at first, he soon abandoned his practice for he did not like what he saw in Russia (Nagy: 1934). Nagy's claim on note-taking is contradicted, however, by his own words taken from his published travelogue. He wrote, for example, that on their visit to a state farm towards the end of their tour he jotted down twenty pages of notes and that "during my walks on the streets I took notes" [utcai sétáimon feljegyzéseket csináltam] (Nagy 1989: 142, 159). These comments negate what he stated in his review and may indicate that during his Russian travel he never gave up on publishing his impressions upon his return to Budapest. His travelogue was published serially in the weekly Szabadság ['Freedom'] from October 6, 1934 to May 12, 1935. It was published in book form only in 1989 during the dying days of communism. The editors of his book included an annex containing some remnants of his diary written during his Russian trip. His diary serves as further proof that he took constant notes while he was in Russia.

Nagy in his review went on to note that in the travelogue Illyés "with a writer's eye and perspective" [írói szemmel, irói szemlélettel] was able to overcome his own feelings and acted as an objective judge at court. Nagy declared that though he uses the same method to describe the same voyage they took together, the results are not the same. He found Illyés's work more readable than his own which stressed cold facts and his disappointment with what he saw in Russia. In the same review, however, Nagy then proceeded to undermine his earlier judgment on his travel partner's objectivity. He writes that Illyés's work was more readable than his own because "He lets himself be a poet. He conceals, deconstructs, dramatizes, invents. Consequently, he fills the gaps between facts for the reader with lively material, evocative of life... The way I see it, reality is better described by the invention of the poet than the almost embarrassing affirmation of witness testimony" [megengedi magának, hogy költö legyen. Elhallgat, felbont, dramatizál, kitalál. Ez által a tények közti ürt is kitölti, mégpedig élö, az életet az olvasó számára megjelenitö anyaggal...Úgy látom, hogy a valóságot jobban ábrázolja a költő kitalálása, mint a tanúvallomáshoz való szinte kínos ragaszkodás] (Nagy 1934).

Nagy's backhanded compliment recalls Illyés's approach in his review in which he invented stories, twisted Duhamel's words, or neglected to describe crucial issues that were in the travelogue. Nagy in his review, therefore, describes not only his own approach of sticking to the facts, but also warns the reader that Illyés's travel writing is unreliable as a documentation of Russian life. Nagy's view is also borne out by Illyés's own words, who in his travelogue claims that he is providing an objective report, but his veracity is contradicted by a conversation he had with the prominent Hungarian writer and editor in chief of Nyugat, Mihály Babits. Before his departure to Russia, he confided to Babits that it was his intention to write a positive report. Illyés exclaimed, "I will not write the truth!" [Nem írom meg az igazat!] (Hammerstein 2007). His travelogue, however, starts with a grammatically incorrect quote in Russian which ostensibly was made by an acquaintance Illyés met in Russia: "Write the truth!" [Pisitye právda[sic]]! The call in the imperative indicates that his reader will find nothing but the truth in the book. Following the war, however, during the early days of Soviet occupation in July 1945, Illyés contradicted his earlier claim. In his diary he recalled his April 12, 1935, conversation with the 
Pastor, Peter. "The Travelogues of Gyula Illyés and Lajos Nagy on Their Visit to the Soviet Union.” Hungarian Cultural Studies. e-Journal of the American Hungarian Educators Association, Volume 11 (2018) DOI:

right-wing authoritarian prime minister, Gyula Gömbös. Gömbös asked him if his book about the Soviet Union was absolutely truthful. Illyés replied in the negative, not revealing who had kept him from writing the truth: "As much as they made me keep quiet about what was praiseworthy, on my own accord I have kept quiet just as much about what I found objectionable. I had to weigh things that way so that the final impression would still reflect reality" [Amennyit elhallgattattak velem még így is a dicsérendöböl, ugyanannyit hallgattam el önszántamból a kifogásolandóból. Így kellett mérnem a dolgot, hogy a végleges benyomás azért mégis a valóságnak feleljen meg] (Illyés 1986: 94). Illyés later claimed that it was the prime minister's press secretary, István Antal, who had pressured him not to be entirely truthful (Illyés 1986: 91-92).

In his diary entry written for publication in 1974 during the zenith of the communist Kádár regime, Illyés mentions that while reading the page proofs for the republication of his travelogue he noticed his work's "unique truth" [sajátságos igazságát]. He declared that the book

intended to support those who suffered, a suffering people. Back then the image of the Soviet Union was besmirched in Hungary. For this reason I could not place a black mark on its image which due to the circumstances would have been a sham... Today I would write it differently.

[szenvedöket akart támogatni, egy szenvedö népet. A Szovjetuniót akkor még Magyarországról csak bemocskolás érte. Sötét foltot én azért nem rakhattam rá-a kép így-a helyzet folytán-hamis lett volna...Ma másként írnám] (Illyés 1990: 76).

Illyés's subjectivity in the travelogue comes into sharp focus at the very beginning of his book as he describes his experiences when crossing the Polish-Soviet frontier by train and reaching the Soviet border station of Negoreloe. His description of his arrival indicates that he brought his prejudices with him from Hungary. Illés writes:

On the wide platform of Negoreloe station eight soldiers are standing in a line formation. They have no weapons. The commanding major has the only gun, a small revolver. He wears huge knee-high boots, a pair of breeches and lots of belts and shoulder straps. With his fiery red curls flowing from under his cap and his huge oriental nose he stands out like a poster aiming to inform the arrivals that the Soviet does not recognize the difference among peoples

[Nyegorjeloje széles peronján nyolc katona áll sorfalat. Fegyver nincs náluk. Fegyvere, apró revolvere csak a parancsnokló örnagynak van, aki térdig érö, hatalmas csizmában, bricseszben, rengeteg derék- és vállszíja között, sapkája alól kilángoló göndör, vörös fürtjeivel és termetes keleti orrával úgy mered ott mint egy plakát, hogy harsányan tudassa az érkezökkel: a szovjet nem ismeri a fajták közti különbséget] (Illyés 1934: 13).

Illyés's description of the officer is reminiscent of the figures of anti-Semitic cartoons in right-wing newspapers in interwar Hungary and Central Europe. His framing suggests that contrary to Soviet propaganda the Jews are in control and this is indicated by the symbolic fact that the only gun was in the Jewish major's hand. For the attentive Hungarian reader for whom the book was written, the message was loud and clear: in the USSR the Jews are in charge. In the 
Pastor, Peter. "The Travelogues of Gyula Illyés and Lajos Nagy on Their Visit to the Soviet Union.” Hungarian Cultural Studies. e-Journal of the American Hungarian Educators Association, Volume 11 (2018) DOI:

1974 edition Illyés did his best to be politically correct and the classic anti-Semitic stereotypic tropes, the "fiery red" and the "oriental" were omitted.

In another part of the 1934 version of the travelogue Illyés exclaims how proud he is of being able to identify ethnics by their looks, including who is a Jew. In the section entitled $A$ proletár Moszkva ['The Proletarian Moscow'], he writes, "gradually I pick out the faces as well. Under the Russian, Tatar, Jewish, Caucasian features the faces also show mainly the international marks of the proletariat" [lassanként az arcokat is felfedeztem. Orosz, tatár, zsidó, kaukázusi vonások alatt az arcok is jórészt a proletárság nemzetközi jegyeit mutatják...] (Illyés 1934: 18). It is noteworthy that from the text of the 1974 edition the "Jew" was left out (Illyés 1974: 28). Thus, reading the republished travelogue one can note that forty years after the first edition and thirty years after the Hungarian Holocaust, it was no longer acceptable to brag about the author's talent of being able to distinguish between Jew and Gentile. This case is additional proof that Illyés was not completely truthful when in his 1974 preface he indicated that he made no changes in his 1934 travel writing. Illyés justified his alleged objection to changes in his travelogue by writing: "There are works that crumble, crack when touched at a later date. Those that are of interest, or perhaps of value, belong closely to the past and at the same time to the development in moral fiber" [Vannak azonban müvek, amelyek törnek, repednek késöbbi hozzányúlásra. Azok, amelyeknek az az érdekességük-értékük tán一, hogy szorosan hozzátartoznak az időhöz és ugyanakkor egy jellem fejlödéséhez] (Illyés 1974: 7-8). He was right in these remarks, but since without alluding to it, he retouched his republished work, one can conclude that Illyés demonstrated a certain weakness in his own moral fiber.

It is significant that Duhamel in his travelogue also commented critically on the apparently frequently voiced claim that the Jews were in charge in the Soviet Union, which Illyés repeated in his travel book. Duhamel wrote:

Are they today really in charge? Are they everywhere? That is without a doubt the convenient theme to liven up anti-Semitic passions which have not been crushed yet among the Western masses. To tell the truth, the Jews in old Russia could not occupy any eminent positions which they now take, just as they have in France, and in England, where they are treated according to their merits and labors. And the Russians in turn must get used to that since that is how global justice goes. In a free competition the one who is able triumphs.

[Sont-ils aujourd'hui vraiment les maîtres? Sont-ils tout? Voilà sans doute un thème commode pour aviver les passions antisémites qui ne sont pas encore éteintes dans foules occidentales. A vrai dire, si lés Juifs, dans l'ancienne Russie, n'occupaient aucune des places éminentes, ils ont pris aujourd'hui, comme chez nous, comme en Angleterre, toutes celles que leur assignent leur mérites et leurs travaux. Et les Russes, à leur tour, devront bien s'y habituer, puisque ainsi va la justice du monde. Au concours libre, triomphe qui peut] (Duhamel 1927: 228-229).

Luc Durtain, Duhamel's travel companion, puts the visibility of Jews in Russia, where they were marked as a nationality, in a similar perspective: "The tsarist oppression halted the entry of this persecuted nation to official careers, closed the gates of the universities and thus exposed the roads to the revolution: already marked by the bloody footprints of the pogroms" [L'oppression tzariste, arrêtant la race persécutée à l'entrée des carrières officielles, au seuil des universités, lui avait assez montré les chemins de la révolution: indiqués déjà par les traces sanglantes des pogromes] (Durtain 1928: 296). He also replies to Duhamel's question if the Jews 
Pastor, Peter. "The Travelogues of Gyula Illyés and Lajos Nagy on Their Visit to the Soviet Union.” Hungarian Cultural Studies. e-Journal of the American Hungarian Educators Association, Volume 11 (2018) DOI:

are in charge in Russia: "The Jews are no longer in charge of the soviets in Moscow...But one meets them in large numbers among government officials and intellectuals: Russia loses nothing" [Les Juifs ne sont plus maîtres dans les conseils de Moscou...Mais on les rencontre en grand nombre parmi les fonctionnaires et les intellectuels: la Russie n'y perd rien]. He concludes his comment by declaring: "It seems to me that the Russian people have retained among the old superstitions that survived the turmoil-a pretty strong anti-Semitism" [I me semble que le people russe ait gardé, parmi les superstitions d'antan qui ont survécu à la tourmente, un assez vif antisémitisme] (Durtain 1928: 298).

It is noteworthy that at the end of 1927 when Illyés reviewed Le Voyage to Moscou in the liberal journal Nyugat, it did not occur to him to mention Duhamel's position on fair treatment of the Jews. A favorable comment from Illyés could have been very appropriate in 1927, since the Hungarian Numerus Clausus law, in force since 1920, just as the Numerus Clausus law (protsentnaya norma) of 1887 in tsarist Russia, limited the number of Jewish students at the universities. In Hungary the law denied Hungarian Jews of equal opportunity and advancement on merit. Furthermore, for the first time in Hungarian history the law defined the Jews as a race instead of a denomination (Kovács 2012: 69-72). As far as Duhamel's claim of anti-Semitism among the masses in the West was concerned, Illyés's own diary entry of June 28, 1929, confirmed a similar situation in Hungary. On that day he recorded with an air of irony the following conversation by two women workers riding on a Budapest tram: "Cursing the communists. 'Miserable villains, who do not want to work. They are all indigent bums and Jews who want to leech off the proletarians.' Both women appear to be so poor that one could not imagine them being poorer" [Átkozódás a kommunisták ellen. 'Nyomorult gazemberek, akik nem akarnak dolgozni, '-'Mind nincstelen csavargó és zsidó, akik a prolikból akarnak élni. 'Mind a két nö oly szegény külsejü, hogy szegényebbet képzelni sem lehet] (Illyés 1986: 10). In light of his familiarity with Duhamel's book and his awareness of everyday anti-Semitism in Hungary, Illyés's cynical comment about the Jewish major as poster boy in Negoreloe indicates that he could hardly be called an "unbiased reporter of Clio."

While Illyés in his literary exposition indicated that in the USSR the Jews are in charge, Nagy, who also brought along his own prejudices, seemed to be preoccupied by the sight of Jews everywhere during his visit. This is reflected more in the diary notes and less in the travelogue. In his July 21, 1934, entry he penned in Kharkov, he notes: "The hotel, here too, is full of Jews. This was also the case in Rostov" [A szállodában itt is csupa zsidó van. Rosztovban is így volt]. And as far as the latter city is concerned: "Here there are many pretty women and many Jews" [Itt sok a szép nó és sok a zsidó]. In his July 24, 1934, entry from the Dnieper Hydroelectric Station, DneproGES, he complains about his hotel where nothing works: "The bathroom is appalling, bed appalling. It is like a trough. I was more comfortable at the military barracks in Piliscsaba. My life was better too" [A fürdöszoba rémes, Ágy rémes. Mint egy teknö. A piliscsabai katonai barakktáborban jobban voltam elhelyezve. Életem is jobb volt]. Then he adds: "Every new guest is a Jew" [Minden új vendég zsidó] (Nagy 1989: 169-170, 176). On the boat to Odessa he writes in his diary that the vessel has a two-class accommodation and notes that "In the first class there are many Jews" [Az elsö osztályon sok a zsidó] (Nagy 1989: 181). In this observation the subtext is that the Jews live better than the non-Jews.

In the published installments of Nagy's travelogue that appeared in Szabadság, however, his prejudices were toned down. This also indicates that published travelogues may carry different messages than the unpublished drafts. One could merely wonder why Nagy tempered 
Pastor, Peter. "The Travelogues of Gyula Illyés and Lajos Nagy on Their Visit to the Soviet Union." Hungarian Cultural Studies. e-Journal of the American Hungarian Educators Association, Volume 11 (2018) DOI:

his words when, as mentioned earlier, in Hungary anti-Semitism was part of the Zeitgeist. Could it be that he did not want to hurt the feelings of his Jewish wife, or it may just be, as the literary critic Ákos Szilágyi noted, Nagy "in 1934 did not come to like the Soviet Union, but he liked even less Horthy's Hungary" [in 1934-ben nem szerette meg a Szovjetuniót, de még kevésbé szerette Horthy Magyarországát] (Nagy 1989: 25). Perhaps because he admitted to having "petty bourgeois prejudice" he did not wish to flaunt his anti-Semitic feelings either. In the travelogue he describes that in Leningrad he was put up by Intourist in the first-class Astoria hotel. "In the evening in the hotel I observe that the cleaner of the public toilet, the so-called loo lady, is a man of patriarchal age. This is an unpleasant surprise. But I recognize that my surprise is based entirely on my petty bourgeois prejudice. For if it is necessary to follow this occupation, why should the person in question be a woman rather than a man" [Este a szállóban azt tapasztalom, hogy az illemhely takarítója, magyarul klozettosasszony, egy patrialkális korú férfi. Ez kellemetlenül lep meg. De elismerem, hogy meglepödésem meröben kispolgári elöitéleten alapszik. Mert ha muszáj valakinek ezt a foglalkozást üzni, miért legyen az illetö inkább nö, mint férfi] (Nagy 1989: 100)? This confession in the travelogue seems to be the one of the rare observations in which Nagy admits that he can see something positive from his Soviet travel experience.

In his travelogue Nagy also makes a comparison between Jews of the West and Russia. He mentions that in Rostov he is visited by the president of the local cultural alliance, a certain comrade Stein. Nagy goes on to say that Stein is Jewish and he only mentions this because his guest does not know German. He writes that even in Moscow, but more so in the east and south Jews do not speak German. He notes: "It may be that this minor curiosum does not interest others, but I found it interesting as this is something I never experienced before" [Lehet, hogy másokat az ilyen apróság nem érdekel, de én rendkívül érdekesnek találtam, mert számomra még soha nem tapasztalt kuriózum volt $]$. With the same kind of wonderment he writes: "The Jews of Russia are obviously different from the West European Jews: I saw militant tough people among them" [Az oroszországi zsidók nyilván különböznek a nyugat-európaiaktól: harcias, kemény embereket láttam közöttük] (Nagy 1989: 150-151). Clearly, Nagy is thinking in stereotypes: the Jews in the West, and what he really means is in Hungary, speak German and are effete. This assumption is borne out by another observation of his. Upon his return to Moscow he was put up in the Novo-Moskovskaia hotel. One of the managers of its restaurant was a Hungarian emigré. Nagy commented: "Incorrigible! He will never shake off his Hungarian, in fact Budapest, in fact Budapest Jewish societal attitude. He told me with veritable rapture that the little Mongol woman sitting alone at the hall's outermost table is 'an aristocratic lady, princess. The management issued an order that she must be treated with exceptional courtesy"' [Javithatatlan! Magyar, söt pesti, söt pesti zsidó társadalomszemléletétöl sohasem fog megszabadulni. Valóságos áhítattal közölte velem, hogy a terem szélső asztalánál magányosan ülö kis mongol nö, 'igen elökelö nö, hercegnö, ki van adva a vezetöség részéröl a parancs, hogy megkülönböztetett udvariassággal kell vele bánni'] (Nagy 1989: 124). These observations and encounters with Jews Nagy writes about in his travelogue and diary notes clearly mirror his own societal attitudes, which are similar to those of Illyés: one must always know who is and is not a Jew.

Even though they traveled together, Lajos Nagy, perhaps in response to Illyés's travelogue in which he was not mentioned, also made a non-person out of Illyés in his own travel writing. As did Illyés, Nagy noted mounted guards with arms at the Soviet border, but for him this was nothing out of the extraordinary as "in every civilized country they guard with weapons 
Pastor, Peter. "The Travelogues of Gyula Illyés and Lajos Nagy on Their Visit to the Soviet Union." Hungarian Cultural Studies. e-Journal of the American Hungarian Educators Association, Volume 11 (2018) DOI:

so that the border would not be crossed without permission"[minden kultúrországban fegyverrel vigyáznak arra, hogy a határt engedély nélkül senki át ne lépje] (Nagy 1989: 31). Nagy, in contrast to Illyés, made no mention of the sentry on the platform of Negoreloe station. On going through customs checks, both accounts are similar and from Nagy's book we learn that Illyés came equipped with a camera, while Nagy did not have one. Some of the photographs Illyés took with his camera were included in the travelogue's recent publication in Russia. This book, based on the 1974 version, was published in 2005, seventy-one years after its Hungarian publication and fourteen years after the collapse of communism. Clearly, the full text of Illyés's travelogue was not to the liking of Soviet officialdom and during the fifties only selected parts appeared there, even though many of his literary works were translated into Russian. Works by Nagy that were highly critical of Russia were not translated at that time. Surviving fragments of his unpublished travel diary appeared together with the original travelogue was published in a book form for the first time only in 1989 during the waning days of communism.

In Illyés's travelogue published in 1934, there were forty-seven in-text photos of poor quality, mostly propaganda pictures from official Soviet sources (Fejér 2005). No photos were included in the two postwar editions. The recent Russian publication has sixteen photos, including two separate photos of the travelers in Moscow who probably took these of each other. Though the captions are brief and are not specific enough, thirteen of the pictures can be connected to Illyés's text, indicating that these photos were taken by the author (Illyés 2005: 225-233). The photos in both the Hungarian and Russian editions offer positive representations of the situation in the USSR. They show modernization and a satisfied society. The texts of the travelogues, however, contradict the messages of the photos (Illyés 1974: 186, 189, Nagy 1989: 142). An example of a positive photo is a picture of a combine with the simple caption "Harvest" [Uborka urozhaya]. The conclusion of the uninitiated viewer could be that in modernizing Russia the collective and state farms are mechanized and the harvests are bountiful. Yet Illyés's description of a guided visit to a model farm is less rosy: "Out in the fields they were harvesting. The grain, as I said, is full of thistle, poppies, and corn cockle" [Künt a határban éppen arattak. A gabona, mint mondtam, tele van bogánccsal, pipaccsal, konkollyal] (Illyés 74: 189). Nagy, on the other hand, notices the sparseness of the corn fields and the weeds there (Nagy 1989: 146).

While Illyés does not say that he who took photos of the harvester, he mentions that: "We halted one or two combines and chatted with the workers" [Megállitottunk egy-két kombájnt, beszélgettünk a munkássokkal] (Illyés 74: 189). This account also implies that there was a friendly exchange between the farm workers and the visitors. Nagy's travel diary also describes the visit to Verblyud State Farm in Zernograd and their talk with the three-man crew of the harvesting combine, but according to Nagy's description the encounter is not a friendly one. "They are terribly indifferent to us, well, rather, they despise us. Oh, in their eyes we are bourgeois globe trotters. Or journalists who come and look around, posing questions with a smile, nod, and at home they describe them as baking little children for lunch" [Rettentöen közönyösek hozzánk, amennyiben nem, hát inkább megvetnek bennünket. Ja, világjáró burzsujok vagyunk a szemükben. Vagy újságirók, akik jönnek, nézelödnek, mosolyogva kérdezgetnek, bólintgatnak, otthon azután azt írják róluk, hogy kisgyerekeket sütnek ebédre] (Nagy 1989: 146). Nagy sees the workers as brainwashed by their government's successful anti-Western propaganda. The two travel accounts about the same episode are diametrically different, indicating the subjective nature of the travelogue genre. 
Pastor, Peter. "The Travelogues of Gyula Illyés and Lajos Nagy on Their Visit to the Soviet Union.” Hungarian Cultural Studies. e-Journal of the American Hungarian Educators Association, Volume 11 (2018) DOI:

Nagy's framing of the workers' behavior towards Western visitors is a response to an initial experience he had soon after his arrival to Moscow. During his visit to the home of a Hungarian expatriate writer, Nagy noticed that the domestic aid, Tatiana, "has in her glance a hatred which is mitigated by some cheerfulness. It is because I am not dressed fully in proletarian fashion" [tekintetében van valami kedélyességgel enyhített gyülölet is. Mert nem egészen proletárosan vagyok öltözve]. The woman "would wring the neck of a couple of bourgeois...The message is for you," [kitekerné egy pár burzsujnak a nyakát... Ez nekem szól], adds the host (Nagy 1989: 62).

Illyés and Nagy also perceive differently the English-language propaganda slogans they found on the wall of the Verblyud state-farm-connected college classroom. "Communism is Soviet power plus electrification.” Naively, Illyés attributes Lenin's famous exhortation to the school's educational language requisites which calls for the study of English and German (Illyés 1974: 188-189). Nagy, who also mentions it along with another slogan taken from Marx's Communist Manifesto, "Proletarians of the World Unite!" is ever more suspicious, looks under the veneer, and offers a more realistic explanation. He thinks that the communist slogans in English are designed for the visitors and serve as further proofs that the state farm is a model institution to impress foreigners: "The English inscriptions indicate that this Verblyud is a bit like a showplace" [Az angol feliratok mutatják, hogy ez a Verbljud egy kissé mégis csak kirakatintézmény] (Nagy 1989: 145).

Still another photo taken by Illyés and reproduced in the Russian translation has the simple caption: “A Ukrainian Man” [Ukrainets] (Illyés 2005: 233). In Illyés's 1934 travelogue the same photo's caption reads: "Ivanisov, the leader of the kolhoz." [Ivaniszov, a kolhoz vezetöje] (Illyés 1934: 179). It shows a man in a white shirt, a Tatar cap on his head, a pencil in his hand standing in front of a utility vehicle. It is a picture of a man exuding confidence. He appears in the narrative of both writers in a similar fashion. He is the chairman of the collective farm in the Ukrainian village of Khortytsa. Comrade Ivanisov used to be a herdsman, later becoming a Red Army soldier and eventuallya model Soviet worker (Nagy 1989: 161, Illyés 1974: 209). Illyés explains that according to Ivanisov, most peasants joined the kolhoz "during the war against the kulaks" [a kulákharcok idején léptek be] (Illyés 1974: 209). Illyés correctly saw the process of forced collectivization as the communist revolution on the countryside, "a second revolution" [egy második forradalom] (Illyés 1974: 190) and questioned the wisdom of the process writing: "But was it necessary to take this bloody detour? Why was it necessary to keep open the trap of 'embourgeoisement' for the peasantry? To this question of mine a few referred to the all-absolving 'historical necessity,' a term I learned to hate" [De vajon szükséges volt-e ez a véres kerülö? Miért kellett a parasztság számára a "polgáriasodás” csapdáját nyitva tartan? E kérdésemre néhányan a minden alól feloldó "történelmi szükségszerüségre” hivatkoztak, amelyet már megtanultam gyülölni] (Illyés 1974: 195). Nagy was also uncomfortable with Ivanisov's explanation of the so-called war against the kulaks and asked the kolhoz chairman about the fate of the landowning peasants, the kulaks. "He responded with a smile. We liberated the land from them. The answer did not satisfy me, and puzzled me." [ $O$ mosolyogva csak ennyit felelt: megszabaditottuk tölük a földet. A felelet nem elégített ki, zavarba ejtett] (Nagy 1989: 161).

Since Ivanisov's model collective farm was close to DneproGRES hydroelectric station and the farm machinery was run on electricity. Illyés noted, "This was the place where I saw a milking machine for the first time in my life" [Itt láttam életemben elöször elektromos fejögépet] 
Pastor, Peter. "The Travelogues of Gyula Illyés and Lajos Nagy on Their Visit to the Soviet Union.” Hungarian Cultural Studies. e-Journal of the American Hungarian Educators Association, Volume 11 (2018) DOI:

(Illyés 1974: 212)." At this point a modern traveler could have elaborated how this machinery could also be used to increase milk output on Hungarian farms if they had electricity, as most did not. Neither of the travelogues offers examples of how the positive practices from an "alien" culture could be successfully adopted for use at the home country. In that sense these are traditional travel writings representing the way travelogues were written before the twentieth century. Emphasis is on the descriptive rather than on the analytical (Whitfield 2011: 244). A contrast between the old and new is limited to the Soviet Union proper. Illyés's observation in connection to his collective farm visit symbolizes this approach: "We drove by the cemetery, I saw recently-made wooden crosses but, as a sign of progress, two were cobbled together with rails" [Temetö mellett haladtunk el, láttam friss keresztet is, nem csupán fából, hanem kettöt - a haladás jelképe —vasúti sínböl összeróva] (Illyés 1974: 214).

While Illyés was impressed by the peasant life on the showcase state- and cooperative farms, on the last stop of his itinerary, in Gorky Oblast ['region'] (formerly Nizhegorod Oblast) to his great surprise he saw no progress, just the age-old peasant poverty. Expressing disappointment he wrote: "I do not understand the whole thing. In the Nizhny district the peasantry was always poor, as whenever Lenin offered an example of the impoverishment of the Russian people he always mentioned this area....The situation has not changed since then" [Nem értem az egész dolgot. A nyizsnyiji kerületben a parasztság mindég szegény volt, hisz Lenin is valahányszor az orosz nép nyomorával példálózott, mindannyiszor ezt a környéket emlegette...A helyzet azóta sem változott] (Illyés 1974: 256). Stopping at one of the district's villages, he visited one of the homes. Evidently what he saw indicated that living conditions had not changed there since tsarist times. The family and their livestock lived together under the same roof: "The small rooms are crammed with furniture and ficus trees. From the kitchen a couple of steps lead down to the stables and the roomy barn" [A kis szobák tele vannak zsúfolva bútorral és fikusszal. A konyhából egy két lépcső vezet le az istállóba és a tágas fészerbe] (Illyés 1974: 257).

While in his travelogue Illyés held back from making comparisons between Hungary and Russia, he gave his feelings free rein in his September 1938 diary entry as he recalled his visit to the Russian countryside. He noted that until he took his tour in Russia he had compared the Hungarians with Westerners and claimed that his compatriots did not measure up to them. But compared to what he saw on the former tsarist- and boyar-ruled lands, he could feel proud of being Hungarian.

I thought to myself, in your country you call this tillage, planting of rye? Is this a house for you (the cow and man lived together), is this apiculture for you? And I began to swell with pride. I remember dawn and being emotionally moved when coming from the direction of northern Russia with its monotone landscapes of birch trees and dwarf pine shrubs, and when around Odessa appeared, at last, the acacia tree, the first white washed house, well swept! How dear they all became suddenly, all that I saw at home as being undesirable. Even on the acacia hitherto I noticed only the dust.

[Nálatok ezt híjják szántásnak, rozsvetésnek-gondoltam ott-, ez nektek ház (a tehén és ember együtt lakott), még csak így tudtok méhészkedni? -s az én derekam is egyszer egyenesedni kezdett. Emlékszem a hajnalra, meghatottságomra, mikor a felsö orosz tájak felöl jövet a monoton nyírfa és törpefenyö-cserjések után Odessza környékén feltünt végre az akácfa, az első meszelt ház, gémeskút! Milyen értékes lett egyszeriben mindez-mindaz, aminek otthon csak a hátrányát láttam. Még az akácon is eladdig csak port láttam] (Illyés 1976: 366-367). 
Pastor, Peter. "The Travelogues of Gyula Illyés and Lajos Nagy on Their Visit to the Soviet Union.” Hungarian Cultural Studies. e-Journal of the American Hungarian Educators Association, Volume 11 (2018) DOI:

While such a forceful criticism of agrarian Russia and the comparative approach is missing in Illyés's original travelogue, Nagy in his travel writing already implies that agricultural conditions are better in Hungary: "I see everywhere dismally weedy grain....On the same latitude as today's northern Hungary" [Látok mindenfelé rémesen gazos gabonát...A mai Magyarország északi részével egyenlö magasságban] (Nagy 1989: 138).

The 1938 comment is a further indication that Illyés's 1934 Russian travel diary hedged the truth and it shouldbe read with a degree of skepticism. His belated comment reflects an ethnocentric cultural superiority characteristic of the traditional travel diaries written by visitors to exotic lands. For Illyés the symbol of perceived cultural inferiority of the Russians is the peasant who lives under the same roof with his cow. In his writings about Russians this image appears repeatedly. In his travelogue he voices his belief that Soviet progress will never surpass the one in the West. Unlike Lincoln Steffens, Illyés did not discover the utopia that worked in Russia. Near the end of his travelogue he noted: "I do not see that brotherly spirit, the dawning of that paradisiacal new world, which the nineteenth-century intelligentsia debated so much and thought dreamily of in their garrets" [Nem látom annak a testvéries szellemnek, annak a paradicsomi új világnak a derengését, amelyröl a 19. század magántudósai padlásszobáikban annyit vitáztak és álmodoztak] (Illyés 1974: 222). Nagy shares this view when he calls the Soviet guiding star a political impossibility (Nagy 1989: 46).

Illyés's travelogue concludes with his visit to the town of Gorky (Nizhny Novgorod) following which he returned to Budapest, ostensibly because he received an urgent letter from the Hungarian capital. Perhaps the real reason was that he did not wish to attend the writers' congress in the first place. He just wanted to see the new Russia that he had read about while all expenses were paid by the hosts. As he wrote the year after his trip, "One cannot expect much from a writers' congress or for that matter from any kind of congress" [Írói kongresszustól, mint általában bármily fajta kongresszustól, nem sokat várhat az ember] (Illyés 1976: 119).

Lajos Nagy's travel diary has only a brief paragraph about Nizhny Novgorod. Since the writers' congress had not started yet, he embarked on a visit with his guides to the Autonomous Soviet Republic Chuvashia. He considered it as the most interesting stop of his tour. He wrote: "I observed little that was bad and a lot that was good" [kevés rosszat és sok jót tapasztaltam]. From among the good, he "saw the kind of success of collective farming from which the inhabitants can live tolerably" [láttam a kollektív mezögazdálkodásnak olyszerü sikerét is, hogy a lakosság már türhetöen meg tud élni] (Nagy 1989: 163-164). With his account of what he saw in Chuvashia, Nagy's travelogue ends abruptly. Reportedly he was prevailed upon by his leftist friends in Hungary to destroy the rest of his manuscript.They found his travelogue overtly realistic, thus critical of the Soviet system. Although he did attend the writers' congress, his impressions, therefore, did not see print. The congress opened on August 17 and closed on September 1. It is not known if while in the hall he had been handed the unsigned protest leaflet of a writers' group which was addressed to the foreign attendees. The writers declared that the Soviet Union was built on a pack of lies and that freedom of speech had been abolished two decades ago. The readers were also informed that"The USSR's network of informers is so comprehensive that even at home we often avoid speaking our minds" (Gorbatova 2014). Judging from the language of Nagy's travelogue, it is unlikely that he would have doubted the veracity of the accusations brought up in the leaflet. If for the sake of his friends he abandoned the publication of his experiences at the writers' congress, still, he must have assumed that the published parts of his Russia travelogue were convincing enough for his readers to make their 
Pastor, Peter. "The Travelogues of Gyula Illyés and Lajos Nagy on Their Visit to the Soviet Union.” Hungarian Cultural Studies. e-Journal of the American Hungarian Educators Association, Volume 11 (2018) DOI:

own conclusions about the true nature of communism in Russia. In this sense, Nagy's travelogue is complete, just as Illyés's was, although the latter had prematurely returned to Hungary and, as he later claimed, had avoided attending a useless congress.

Although the two travelogues are written in different styles, they are similar in the sense that neither of the two travelers was won over to the communist system by their Russian experience. Illyés's observations reflected more understanding and were less sanguine than Nagy's. Nevertheless, they both looked upon Russia with an air of superiority. In spite of intentions of objectivity, neither of them reached that goal. They had brought along from Hungary ingrained prejudices that they could not overcome. For all their subjectivities, however, they were correct in not seeing in the communist Soviet Union a future that worked. Neither of the two writers lived to see the implosion of the communist state in 1991, but their travelogues can be read as early premonitions of the eventual fate of the Soviet experiment.

\section{Works Cited}

Babus, Antal. 2015. “'Látom a sorsomat e népben' (Illyés Gyula: Magyarok)" [“I See My Fate in This People (Gyula Illyés: Magyarok)]. Magyar Napló 27 (6): 8-17.

Cœuré, Sophie and Rachel Mazuy. 2012. Cousu de fil rouge ['Sewn with Red Thread']. Paris: CNRS Editions.

Caute, David. 1973. The Fellow-Travelers. A Postscript to the Enlightenment. New York: The Macmillan Company.

David-Fox, Michael. 2003. "The Fellow Travelers Revisited: The 'Cultured West' through Soviet Eyes." The Journal of Modern History 75 (2): 300-355.

Duhamel, Georges. 1927. Le Voyage de Moscou ['The Moscow Trip']. Paris: Mercure de France. Durtain, Luc. 1928. L'autre Europe. Moscou et sa foi ['The Other Europe. Moscow and Her Faith']. Paris: Gallimard.

Fejér, Zoltán. 2005. "Illyés Gyula, a fényképező író." Fotómüvészet 48 (5-6). http://www.fotomuveszet.net/korabbi_szamok/200556/irodalom_es_fenykepezes_3 resz ?PHPSESSID=c421c98f8848f526a5512644bc4c39c3,

Hammerstein, Judit. 2007. "Illyés Gyula, Nagy Lajos és André Gide a Szovjetunióban. II. Rész" ['Gyula Illyés, Lajos Nagy and André Gide in the Soviet Union']. Új Nautilus. Irodalmi és Társadalmi Portál.May 13. http://ujnautilus.info/illyes-gyula-nagy-lajos-es-andregide-a-szovjetunioban-ii-resz

Hurcombe, Martin, Angela Kershaw and Martyn Cornick. 2017. "Radical Departures and the Politics of Inter-war Travel Writing." In French Political Travel Writing in the Inter-war Years. Radical Departures. Ed. Martyn Cornick, Martin Hurcombeand Angela Kershaw. London: Routledge: 1-25.

Illyés, Gyula (Dyula Ijesh). 2005. Rossiya.1934 ['Russia. 1934']. Moscow: Khroniker. . 1990. Naplójegyzetek. 1973-1974 [Diary Notes]. Budapest: Szépirodalmi Kiadó 1986. Naplójegyzetek. 1929-1945 [Diary Notes]. Budapest: Szépirodalmi Kiadó. 1976. Magyarok ['Hungarians']. In Itt élned kell. 1939 ['You must live here.' 1939]. (Budapest: Szépirodalmi Kiadó). 
Pastor, Peter. "The Travelogues of Gyula Illyés and Lajos Nagy on Their Visit to the Soviet Union." Hungarian Cultural Studies. e-Journal of the American Hungarian Educators Association, Volume 11 (2018) DOI:

. 1974. Oroszország 1934 ['Russia 1934’]. In Szíves Kalauz. Útirajzok [Friendly Guide. Book of Travels]. Budapest: Szépirodalmi Könyvkiadó.

. 1934. Oroszország. Utijegyzetek ['Russia. Travel Notes']. Budapest: Nyugat Kiadás. . 1927. "Duhamel Oroszországában" ['Duhamel in Russia']. Nyugat 20, (22): 713-717. http://epa.oszk.hu/00000/00022/00431/13483.htm.

Kovács, Mária M. 2012. Törvénytöl sújtva. A numerous clausus Magyarországon, 1920-1945

['Disenfranchised by Law. The Numerus Clausus in Hungary, 1920-1945']. Budapest: Napvilág Kiadó.

Kershaw, Angela, Martin Hurcombe and Martyn Cornick. 2017. "Political Peregrinations, the Journey Home, and the Sense of Self: Functions of Political Travel Writing in Inter-war France.” In French Political Travel Writing in the Inter-war Years. Radical Departures. Ed. Martyn Cornick, Martin Hurcombe and Angela Kershaw. London: Routledge: 254289.

Mazuy, Rachel. 2002. Croir plutôt que voir? Voyages en Russie Soviétique (1919-1939)

[Believing Rather Than Seeing? Travels in Soviet Russia (1919-1939)]. Paris: Editions Odile Jacob.

Nagy, Lajos. 1989. Tízezer kilométer Szovjetoroszország földjén [Travel of Ten Thousand Kilometers Through Russia]. Budapest: Interart. . 1934. "Illyés Gyula: Oroszország," Nyugat 27, (23-24): 603-604. http://epa.oszk.hu/00000/00022/00587/18382.htm

Rivière, Jacques. 1995. Russie ['Russia']. Paris: Editions L'Aire. . 1984. "Decadence of Freedom." In Jean-Pierre Cap, Decadence of Freedom. Jacques Rivière's Perception of Russian Mentality. Boulder: East European Monographs: 154-160.

Shaw, Bernard. 1964. The Rationalization of Russia. Bloomington: Indiana UP.

Steffens, Lincoln. 1931. The Autobiography of Lincoln Steffens. Vol. 2. New York: Harcourt Brace and Co.

Stern, Ludmila. 2007. Western Intellectuals and the Soviet Union, 1920-40. From Red Square to the Left Bank. New York: Routledge.

Széchenyi, Ágnes. 2015. "Illyés Gyula hétköznapi hadszínterei és hátországai 1939-1945” [“The Everyday Theaters of War and Home Fronts of Gyula Illyés 1939-1945']. In Háborús hétköznapok hadszíntéren, hátországban 1939-1945 ['Wartime Everyday in the Theater of War, on the War Front 1939-1945']. Ed. György Gyarmati, Judit Pihurik. Pécs: Kronosz: 61-76.

Whitfield, Peter. 2011. Travel. A Literary History. Oxford: The Bodlean Library. 